\title{
Communication
}

[Comunicação]

\section{Injuries in cage-bred wild rabbits (Oryctolagus cuniculus) caused by the size of the orifices in the cage floor}

\author{
[Lesões em coelhos silvestres (Oryctolagus cuniculus), mantidos em cativerio, causadas pelo tamanho \\ dos orificios no piso da gaiola]

\section{P. González-Redondo}

Dpto. Ciencias Agroforestales - EUITA - Universidad de Sevilla

Ctra. Utrera, $\mathrm{km} 1$

41013 Sevilla - Spain

The scarcity of wild rabbits (Oryctolagus cuniculus) as a result of myxomatosis and viral hemorrhagic disease has led to restocking in countries such as Spain, Portugal, and France. Part of such restocking requires animals to be bred in captivity, and the game farms breeding wild rabbits in strict captivity normally use cages designed for domesticated breeds. Given the adaptability of the species to management under controlled conditions (Löliger, 1992; Verga, 2000), the results are satisfactory (GonzálezRedondo, 2003). However, some designs of industrial rabbit-breeding cages do not guarantee the minimum conditions of health and welfare when they are used for wild rabbits because they cause injuries, contravening the main function required of housing: that of securing the animals for prolonged periods free of the risk of producing bodily injuries or diseases (Löliger, 1992). In the absence of literature on the rearing of wild rabbits in cages, the objective of this work was to analyze the unexpected incidence of hind limb injuries in cage-bred wild kits caused by unsuitably-sized orifices in one type of flooring, and to propose improved designs in order to enhance animal welfare at game farms.

During a trial of growth in captivity performed in Córdoba, Spain, on 96 cage-born wild rabbit kits (O. cuniculus), originated from the Southern Iberian Peninsula, unexpected, accidental hind leg injuries occurred. The kits were weaned at 30-day-old, and, until day 86, were housed in grouped litters (average number of kits per cage $=2$ ) in metal mesh cages with a $38 \times 51 \mathrm{~cm}$

Recebido em 22 de agosto de 2008

Aceito em 15 de setembro de 2009

E-mail: pedro@us.es base (Fig. 1), similar to those used for meat rabbits (Lebas et al., 1996). The cages were located outdoors in a Dry Mediterranean-type climate (average temperature $=18^{\circ} \mathrm{C}$ ). The cage floor was made using plastic plates ${ }^{1}$ for a resting surface with oval, $12 \times 35 \mathrm{~mm}$ orifices, with a separation of $18 \mathrm{~mm}$. Incidents to kits were enumerated and divided into two categories (Table 1): i) accidents to the hind limbs caused by their becoming trapped in the orifices of the cage floor, and ii) other causes (escape; death from myxomatosis, enteritis, cachexia, heatstroke, and sudden death).

In order to propose a more suitable cage-floor design with smaller orifices, minimizing hind limb injuries, the longer cross-section diameter of 50 fecal pellets of meat rabbits (New Zealand White $\times$ Californian), and 50 fecal pellets of cage-bred wild rabbits were measured. The rabbits in both groups were one-year-old, and were fed on commercial pelleted feed containing $16.5 \%$ crude protein, and $16.5 \%$ crude fiber. Statistical analysis was carried out using the SPSS 9.0 program (Manual..., 1999).

Hind limbs became trapped because the body size of the wild rabbit, and therefore limb is much smaller than that of the meat breeds. Wild rabbits in captivity weigh approximately one kilogram (González-Redondo, 2003), whereas meat breeds and lines can weigh $4-5 \mathrm{~kg}$ (Lebas et al., 1996). This difference in size resulted in 12 rabbits with their limbs becoming trapped in cage floor orifices with their phalanges and calcanea becoming longitudinally wedged in the

${ }^{1}$ Extrona S.A. Viladecavalls, Spain. 
orifice. The injuries comprised closed bone fractures (in most cases, of the tibia) or open fractures of the calcaneum, vertebral dislocations, and skin erosions with hemorrhage. Seven $(58.3 \%)$ of the kits suffering accidents to the limbs died as a result of the trauma.

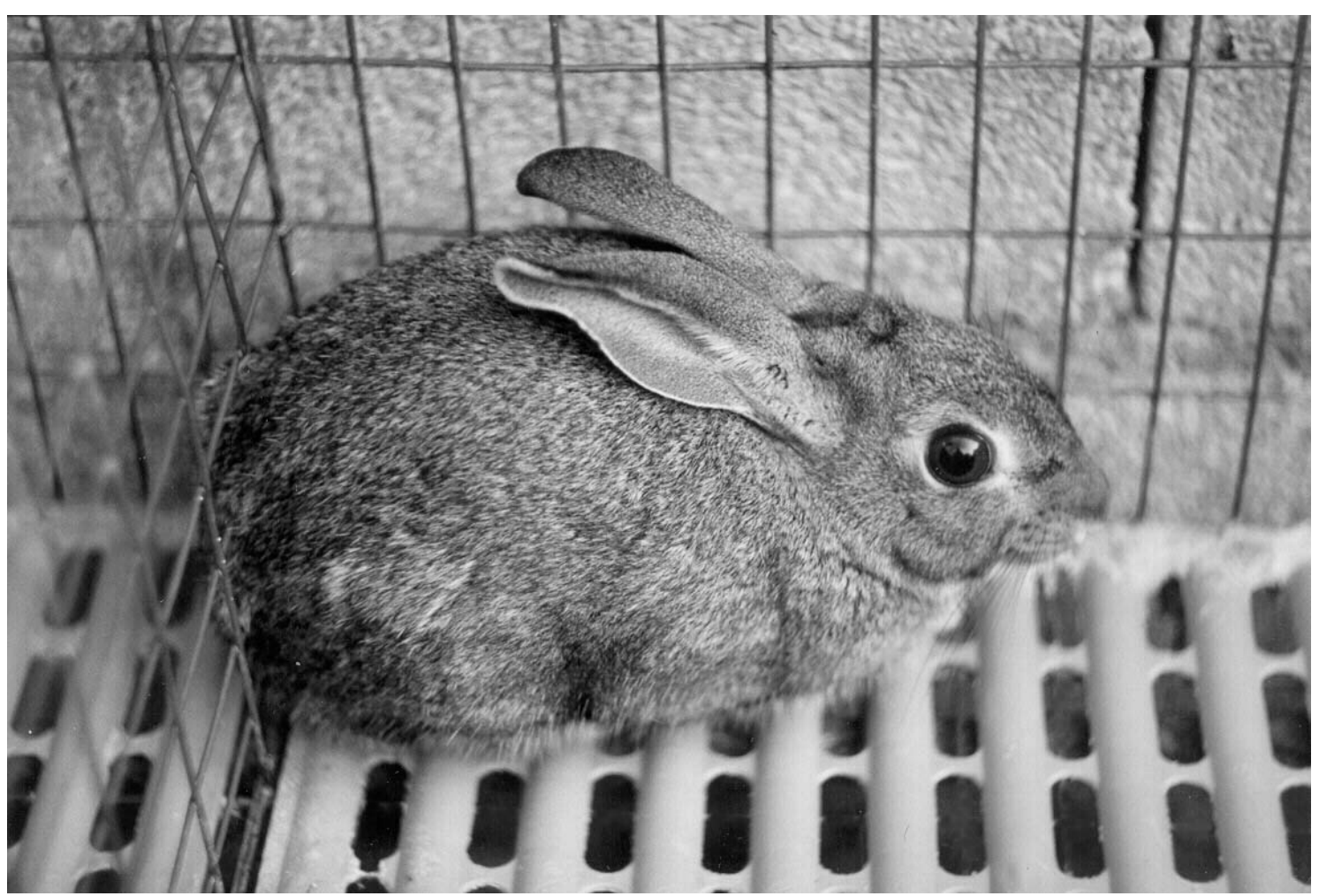

Figure 1. Cage floor in whose orifices the hind limbs of wild rabbits became trapped.

Table 1. Incidents in caged wild rabbits (Oryctolagus cuniculus) from 30 to 86-day-old

\begin{tabular}{lccc}
\hline \multicolumn{1}{c}{ Type of incident } & Number of kits & $\begin{array}{c}\text { Percentage with respect } \\
\text { to the total of kits present }\end{array}$ & $\begin{array}{c}\text { Percentage with respect to } \\
\text { the kits suffering incidents }\end{array}$ \\
\hline No incident & 70 & 72.9 & - \\
Kits with incidents: & 26 & 27.1 & - \\
- Accidents to limbs & 12 & 12.5 & 46.2 \\
- Other causes & 14 & 14.6 & 53.8 \\
\hline Total & 96 & 100.0 & 100.0 \\
\hline
\end{tabular}

Accidents involving hind limbs becoming trapped in the orifices of the cage floor were relatively high and accounted for approximately half the incidents $(12.5 \%$ of the individuals; Table 1) reducing even further the scarce productivity of cage-bred wild rabbits (González-Redondo, 2003). Apart from the kits that died as a result of this type of accident, the limb injuries sustained made the survivors unfit for use either as animals for future breeding or in restocking. For this reason, and in order to prevent them from suffering unnecessarily, injured rabbits were euthanized immediately after their accidents. Concussion followed by exsanguination was performed by an experienced operator, according to the European Commission Recommendations for the euthanasia of experimental animals (Close et al., 1997).

The findings of this study are consistent with those of other authors (Rommers and Meijerhof, 1996), who have shown that the type of cage floor affects the incidence of limb injuries in domesticated rabbits. It has been found that New Zealand White does trapped their limbs in the meshes of a plastic floor with oval orifices 
measuring $20 \times 48 \mathrm{~mm}$, a similar though slightly larger size to those of this study, and suffered bone fractures (Rommers and Meijerhof, 1996).

In meat breeds, the use of a resting surface is recommended to prevent footpad injury (sore hocks or ulcerative pododermatitis) and other limb anomalies, mainly in does (López, 1998). Certain types of cage flooring, mainly grids, are linked to the occurrence of this health problem (Morton et al., 1993). It is also known that the incidence of footpad injuries is lower in domesticated females housed on non-wire flooring such as a solid surface or perforated plastic (Rommers and Meijerhof, 1996). No cases were observed of sore hocks in the wild rabbit kits, possibly because they are much lighter than domesticated breeds, whose weight can be four times that of wild animals. Another factor contributing to the absence of sore hocks is the floor used in the experiment, which was designed to reduce the incidence of sore hocks, and constructed with resting surface plates.

No quantification has been made concerning the effect of floor design (with regard to orifice distribution and size) on the welfare of the kits, but it is known that this factor particularly affects young kits because of their smaller body size. It has been observed in meat breeds, as well as in this study, that the greater the distance between slats, the more the kits made unsure movements (Petersen et al., 2000).

From a joint consideration of behavioral, clinical, and hygiene criteria, it has been proposed that to both safeguard the health and welfare of the rabbits and to enable proper removal of the feces, plastic floors with $10 \mathrm{~mm}$ wide slats with a $14 \mathrm{~mm}$ separation, similar to those used in this study, are acceptable for both does and kits of meat breeds (Petersen et al., 2000). In this study, the solid part of the cage floor between orifices had a width of $18 \mathrm{~mm}$, and a $12 \mathrm{~mm}$ separation between slats, similar to what has been proposed by others (Petersen et al., 2000). However, a relatively high incidence of injuries to the hind limbs occurred because the cage floor orifices were large enough to allow the introduction of the hind limbs, a logical result of the smaller body size of the wild kits. This revealed that the design and size of the orifices in the floor of this study, typical of industrial meat rabbit cages, are not suitable for use with wild rabbits, at least in the first post-weaning months. Since restockings are increasingly performed using rabbits bred in strict captivity (González-Redondo, 2003), it is a minimum requirement that the cages do not cause injuries to the animals. From the viewpoint of safeguarding their health and welfare, the animals should not be able to penetrate, or remain trapped by, the cage floor orifices. There should be no sharp edges and the area of the resting surfaces should be ample (Löliger, 1992).

Although wild rabbits raised on game farms are not normally housed in biomedical research facilities, an analysis of laboratory rabbit cage flooring may offer an additional insight, due to the fact that they are highly effective in ensuring animal welfare. However, the regulations and guidelines regarding the protection and husbandry of rabbits used for experimental purposes do not establish any recommendations concerning the dimensions of the cage floor orifices (Directive..., 1986; Morton et al., 1993). Indeed, the only recommendation is that attention should be paid to cage floor design and that this should vary according to the species and age of the animals. This is aimed at preventing the animals from injuring themselves and, furthermore, they should be designed to facilitate the removal of excreta (Directive..., 1986). Moreover, given the fact that the cages can be fitted with several different types of flooring such as grids, dimples, bars, and slats, it would appear that grid floors may be uncomfortable for the animals and that dimpled patterns are preferable (Morton et al., 1993).

The diameter of the feces of the wild rabbits $(7.9 \pm 0.140 \mathrm{~mm}$; mean $\pm \mathrm{SE})$ was smaller $(\mathrm{t}=-22.44, \quad \mathrm{P}<0.001) \quad$ than that of the domesticated ones $(13.3 \pm 0.197 \mathrm{~mm} ;$ mean $\pm \mathrm{SE})$. Thus, as the mean diameter of the feces of the domesticated rabbit is approximately $60 \%$ greater than that of the wild animal, the slat separation in the cage floor designed for wild rabbits can be substantially reduced. Such a separation could be of some $8 \mathrm{~mm}$, although research under real conditions would be necessary in order to ascertain if this would both solve the problem of trapped limbs and enable feces to be efficiently eliminated.

Although not tested, a better result, in terms of both animal welfare and of fewer injuries caused by accidents from hind-limb entrapment, may be 
obtained by using floors comprising a perforated sheet with circular orifices (Fig. 2), design that is present in some models of rabbit-breeding cages used in small-scale farming. Moreover, a dimple floor has been proposed as the most suitable alternative for keeping rabbits in the laboratory by the BVAAWF/FRAME/RSPCA/UFAW Joint Working Group on Refinements in Rabbit Husbandry (Morton et al., 1993). In fact, most of the commercially-available laboratory rabbit cages are provided with plastic floors whose orifices measure $13-15 \mathrm{~mm}$ in square diameter ${ }^{2,3}$. However, due to the small size of the hind limbs of the kits, this diameter would be too large for use in a cage floor when keeping young wild rabbits. A suitable size for cage floor perforations might have a diameter of about one centimeter. With regard to the floor material, it is clear that a plastic floor may feel warmer than metal (Morton et al., 1993). However, the use of galvanized sheet metal (20 gauge or $1 \mathrm{~mm}$ thick) (Fig. 2) is proposed due to the fact that during this experiment, it was observed that the wild rabbits gnawed the plastic floor of the cages. In conclusion, a galvanized sheet metal cage floor design with circular $10 \mathrm{~mm}$ diameter perforations may eliminate the hind limb injuries and would improve the welfare of the wild rabbits reared on game farms. Further research is needed to confirm the fitness of this proposal.

Keywords: wild rabbit, Oryctolagus cuniculus, animal welfare, hind limbs injuries

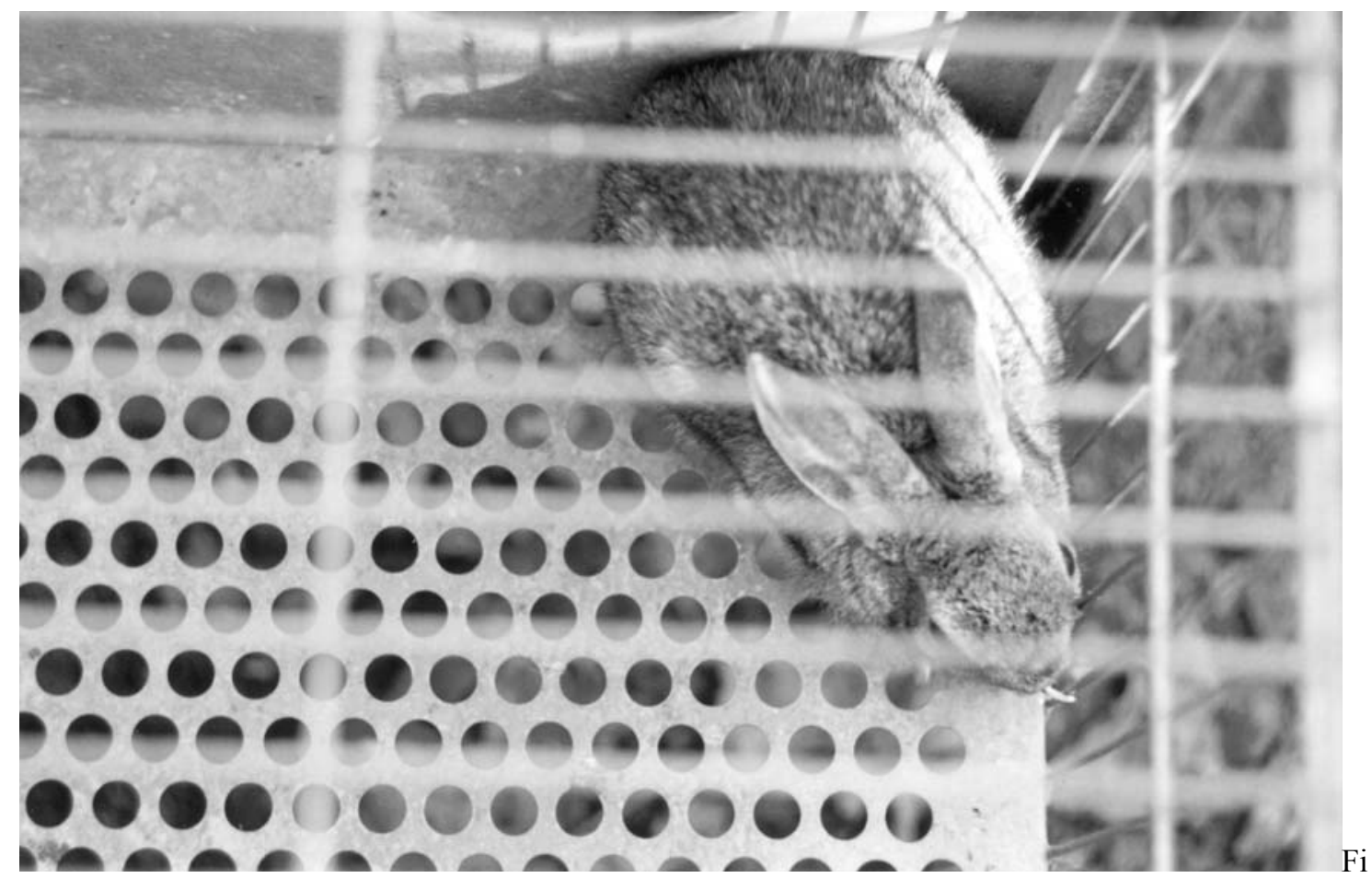

gure 2. Galvanized sheet metal cage floor with circular $10 \mathrm{~mm}$ diameter perforations, proposed to eliminate the hind limb injuries.

\section{RESUMO}

Estudou-se a incidência de lesões nas patas traseiras de láparos de coelhos selvagens (Oryctolagus cuniculus) criados em cativeiro, causadas por inadequação do piso das gaiolas, nomeadamente a dimensão dos orifícios. Propõem-se pisos com dimensões mais adequadas. As gaiolas tinham piso de plástico com orifícios de $12 \times 35 \mathrm{~mm}$ separados em $18 \mathrm{~mm}$. Dos 96 láparos estudados, 12 (12,5\%) sofreram

\footnotetext{
${ }^{2}$ Allentown Caging Equipment Co. - Allentown, NJ, USA.

${ }^{3}$ Tecniplast S.p.a. Buguggiate, Italy.
} 
traumatismos causados pela introdução das patas traseiras nos orificios do piso, e sete deles (58,3\%) morreram. Considerando que o diâmetro das fezes do coelho selvagem é cerca de $60 \%$ menor que o das fezes do coelho doméstico de corte, é possível reduzir em $8 \mathrm{~mm}$ a separação entre os orificios do piso das gaiolas. Como alternativa, o piso poderá ser constituído por orifícios circulares de $10 \mathrm{~mm}$ de diâmetro, o que eliminaria os acidentes causados pela inadequação do piso, melhorando também o bem-estar animal.

Palavras-chave: coelho silvestre, Oryctolagus cuniculus, bem-estar animal, lesões nas patas

\section{REFERENCES}

CLOSE, B.; BANISTER, K.; BAUMANS, V. et al. Recommendations for euthanasia of experimental animals: Part 2. Lab. Anim., v.31, p.1-32, 1997.

DIRECTIVE 68/609/EEC, of 24 November 1986 , on the approximation of laws, regulations and administrative provisions of the Member States regarding the protection of animals used for experimental and other scientific purposes. Off. J. Eur. Comm., v.L358, p.1-29, 1986.

GONZÁLEZ-REDONDO, P. Contribución al conocimiento de la producción del conejo silvestre (Oryctolagus cuniculus) en cautividad estricta. 2003. Tesis (Doctorado) - University of Córdoba, Córdoba, Spain.

LEBAS, F.; COUDERT, P.; DE ROCHAMBEAU, H. et al. El conejo. Cría y patología. Rome: FAO, 1996.

LÖLIGER, H.C. Consideration of animal protection and welfare in domestic rabbit housing and management. J. Appl. Rabbit Res., v.15, p.684-691, 1992.

LÓPEZ, M. Nota sobre el bienestar en la especie cunícola. Rev. Fed. Esp. Asoc. Ganado Selecto, v.14, p.111-116, 1998.
MANUAL del usuario SPSS 9.0. Chicago, IL: SPSS Inc, 1999.

MORTON, D.B.; JENNINGS, M.; BATCHELOR, G.R. et al. Refinements in rabbit husbandry. 2nd Report of the BVAAWF/FRAME/RSPCA/UFAW Joint Working Group on Refinement. Lab. Anim., v.27, p.301-329, 1993.

PETERSEN, J.; SCHLENDER-BÖBBIS， I.; MENNICKEN, L. Evaluation of optimal slat distance in slatted floor for rabbits using behavioural studies. In: WORLD RABBIT CONGRESS, 7., 2000, Valencia, Spain. Proceedings... Valencia. 2000. v.B, p.559-565.

ROMMERS, J.M.; MEIJERHOF, R. The effect of different floor types on footpad injuries of rabbit does. In: WORLD RABBIT CONGRESS, 6., 1996, Toulouse, France. Proceedings... Toulouse, 1996. p.431-436.

VERGA, M. Intensive rabbit breeding and welfare: development of research, trends and applications. In: WORLD RABBIT CONGRESS, 7., 2000, Valencia, Spain. Proceedings... Valencia, 2000. v.B, p.491-509. 